\title{
On the Ability of the Modern University to Meet the Challenges of Sustainable Development
}

\author{
Vadim Mikhalchenko ${ }^{1, *}$, and Irina Seredkina ${ }^{1}$ \\ ${ }^{1}$ T.F. Gorbachev Kuzbass State Technical University, Department of Economics, 650000, Kemerovo, \\ Russian Federation
}

\begin{abstract}
In the article technologies of knowledge transfer at different stages of social development are discussed. The priority and effectiveness of a particular technology of knowledge transfer is determined by the conditions and the state of the external environment. The technology of knowledge transfer is relevant in the conditions of post-industrial development, which is characterized by adaptability and provides a high speed of learning appropriated to the trends of the development of the external environment.
\end{abstract}

\section{Introduction}

Meeting the challenges of sustainable development requires a systematic and balanced consideration of a large number of complex and interrelated issues of economics, sociology and ecology. Consideration of the tasks on this level depends to some extent on the level of knowledge of the society, the relevance of this knowledge and the ability of the higher institution to transfer this knowledge to the rising generation.

In this connection, it seems very relevant to consider the issue of the ability and willingness of the modern higher institution to meet the objectives.

In the history of human and community development, a number of major stages are evident, each of which differs from the previous one not only by the "performance of the productive forces" (people engaged in the production of goods and services, means of labour, technology) [1], the expansion and formation of society's new requirements to the quality of life, but also updating and appearance of new knowledge, the technology of their transfer. Foreign researchers $[2,3]$ distinguish three waves of civilization - pre-industrial (agricultural), industrial, post-industrial (super-industrial society). "Up to the present time, humanity has experienced two huge waves of changes, and each of them mainly destroyed earlier cultures or civilizations and replaced them and lives of people in a way that was incomprehensible to people who lived before" [3].

Pre-industrial society was characterized by the lack of industry and the fact that most of the population was working in agriculture. The system of manual labour was the basis of the production system. Science did not actively participate in social production. Knowledge and technologies were passed on from the older generation to the younger one by the principle of "do the same way". Education, in fact, was disconnected from the labour

*Corresponding author: V.Mikhalchenko@mail.ru 
market - the young people studied the works of philosophers, information about the laws of nature, the heavenly bodies, the surrounding world, and in the medieval period theological dogmas as well. The higher education had no practical significance.

Industrial society appeared in the 18th century because of "talented mechanics" [2] in the process of implementing the first industrial revolution. The starting point of this process was the invention of a steam engine, the potential of which began to be actively used in industry. "Machines began to produce machines", which made it possible to widely use cheap low-skilled labour. It was enough to train workers with elementary skills how to operate the machines. The production process of this period was realized based on the principle "do as you are told". The applied role of the achievements of higher education in public production had increased. At the same time, the mission of the higher school of the late 18th - the beginning of the 20th century was and still remained to create the elite groups. The knowledge was in the focus of the educational process: the professors gave knowledge and they also asked it. Graduates of higher institution were oriented to work not in industrial enterprises, but mainly in universities or specialized, state-funded and / or sponsored scientific institutions.

The second technological (industrial) revolution began in the last third of the 19th century. This period was accompanied by the discovery of new forms of energy (electricity and hydrocarbons) and the subsequent invention of new more productive types of engines (electric motor and internal combustion engine). All this allowed to increase significantly amount of work executed, which contributed to the development of giant enterprises with thousands of employees which used mass production technology.

The transition towards mass production also affected technology of knowledge transfer. The high rates of production of the 20th century, the increasing complexity of technology and equipment, required qualified staff on a massive scale. These specialists were supposed to know the technologies used in the current period and to manage them effectively.

To satisfy the growing demand for qualified specialists, higher education institutions built a system for the knowledge transfer based on the same principles as industrial enterprises, i.e. on the principles of mass production - the stream training of specialists with unified knowledge on the basis of the technology of a class-based learning system. The higher school of the industrial period can be compared with the "factory", where the trainee is the raw material, the teacher is the worker, converting the raw materials into finished good, the technology used is the conveyor. In general, the industrial system of a higher educational institution of the industrial age can be described as a "closed system of a push type". Such systems show their effectiveness in conditions of stable external environment, when demand considerably exceeds production possibilities and, accordingly, everything, what has been produced, is massively consumed.

However, the modern business environment is losing its stability, it is radically changing right before our eyes and demonstrates the ever-increasing pace of change and innovation, the speed and volume of knowledge accumulation is growing exponentially. The experience and knowledge of previous generations are depreciating too quickly.

If the first wave - agricultural - lasted for thousands of years, the second wave industrial civilization - lasted less than three centuries. The modern period shows great acceleration and it is likely that the Third Wave will sweep through the history of mankind and will end in several decades. A. Toffler notes that the formation of the Third Wave civilization is associated with unprecedented technological development [3]. 


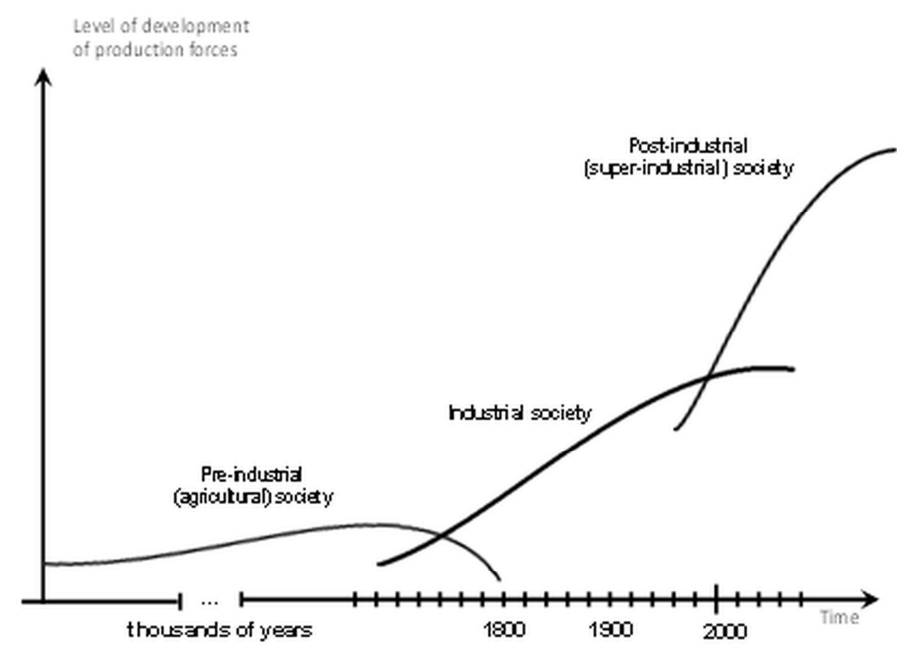

Fig. 1. Three waves of civilization development (according to A. Toffler).

Klaus Schwab [4], president of the World Economic Forum in Davos, points to already unfolding 4th industrial revolution. "We still have to realize the full pace of the development and scope of the new revolution ... Many of these innovations are just emerging, but they are approaching the turning point when they start developing, layering and strengthening each other, representing the intertwining of technologies from the world of physics, biology and digital realities ... Unlike the previous ones, this industrial revolution is developing not by linear, but rather by exponential rates ...".

Future of technologies seems fantastic. According to the forecasts of futurist Ray Kurzweil [6] already "by 2029 computers can prove the presence of their mind. It will be achieved by computer simulation of the human brain. By 2038-2039 - there will be robotic people, products of transhumanist technologies. Nanomachines will be placed directly into the brain and perform arbitrary input and output of signals from brain cells. It will lead to a virtual reality of "full immersion", which does not require any additional equipment. 2044 non-biological intelligence becomes billions more smart than biological. 2045 - the onset of technological singularity (the Earth turns into one giant computer), which by 2099 extends to the entire Universe" [5].

\section{Theory}

All of the foregoing allows us to say that the production systems in the current period, including the systems of training specialists, operate in completely new conditions of the external environment, relative to the period of industrialization. It is an environment with rapidly changing parameters, with a high degree of uncertainty and a level of competition. In the above-mentioned conditions, only highly adaptive systems can remain viable and be successful. systems that are capable to change their structure and / or parameters at a rate much greater than changes in the parameters of the external environment.

It is possible only if these systems have adaptive properties and, thus, correspond to the following two conditions.

The first condition can be designated as the predictability condition:

$$
T_{\text {pred. }} \leq T_{\text {min }}
$$


The fulfilment of condition (1) means that the duration of intervals of parameters planning of production system $T_{\text {pred. }}$ should be selected in such a way that always be within the horizon of reliable forecasting of the environmental parameters $T_{\min }$ (to manage means to predict).

At the same time, at each i-th time step of management it is assumed not only planning, but also implementation of the decision, which requires a certain time $-T_{a d, v}$. This time will characterize the adaptive capabilities of the system, i.e. its inertia. It is quite obvious that choosing a management step smaller than the time characterizing the inertia of the system does not make sense.

Hence follows the limitation on the duration of the implementation period of the action program - the system is able to adapt only if the level of its inertia $\Delta T_{a d . v}$ is significantly less than the period of significant changes in the parameters of the external environment $T_{\min }$.

In accordance with this, we can formulate the second condition of adaptability - the condition of system controllability:

$$
T_{a d . v<<} \Delta T_{\min , v}
$$

Thus, in accordance with the foregoing, when making managerial decisions to determine the parameters of the production system, the characteristics of the parameters of external environment that go beyond the horizon of their reliable prediction - the predictability condition - should not be used, and the production system should be designed in such a way that it can change its parameters or structure faster than changes in the parameters of external environment - the controllability condition [6].

The considered approach to the design of production systems through the imparting of adaptive properties to them, which is addressed, especially, to higher education institutions, has confirmed its high efficiency in practice. The experience of enterprises, leaders of the world economy, functioning in modern unstable and difficultly predicted environmental conditions, showed that the use of these approaches, while building production systems, gives them great vitality and efficiency $[6,7]$.

\section{Discussion}

Success in the formation of adaptive properties in production systems depends to a large extent, if not decisive, on the level and quality of knowledge of specialists, their ability to plan and implement design and management solutions based on existing knowledge.

The main source of this knowledge is still higher educational institutions. Accordingly, higher education institution, in the words of Z. Brzezinski [7], becomes a "think tank" in issues of political planning, social innovation, experiments (in contrast to the University of Industrial Society, which, in fact, is an "ivory tower" - a repository of important, recognized, but inappropriate knowledge).

At the same time, higher education institutions of the present period are not able to solve the problem of providing the economy with qualified staff with adequate changes in knowledge [8]. Theoretical awareness of the crisis of the education system began in the late 60 's - early 70's of the 20th century, after the publication of the book of the English scientist Ph. Coombs "The World Crisis in Education: The View from the Eighties" [9]. Current students, who will work with the technologies of the mid-21st century, are still learning the ideas and technologies of the mid-20th century.

The task of the higher education system is to synchronize the knowledge of future specialists with the pace of changing conditions of management, the development of technology and equipment. In the system of relations with the labour market, universities 
should position themselves as active business partners - suppliers of labour resources, bringing their knowledge in line with the current and prospective needs of the labour market and the economy. The University entered the era when it "creates concrete value for society and begins to cooperate with business" [10]. In other words, the university should release specialists to the market whose knowledge will enable them to work without additional "customization" on the part of employers in the new economic conditions.

To this end, higher education institutions should rebuild their production systems, which, ultimately, have to be able to react flexibly to rapid changes in the business environment, literally "pulling the product requirements" from the consumer and reconfiguring labour, material resources and the technological process of training specialists accordingly to the changing trends of external environment.

From a technical point of view, the production systems of universities of post-industrial economy should provide "serial production" of specialists. This thought (concerning the construction of production systems in general) is expressed also by A. Toffler [3]: “... the essence of the Third Wave Manufacture is the short run of partially or completely customized products".

"Serial production" of specialists in the conditions of a higher educational institution can be realized in the following order.

Firstly, it is necessary to ensure, as it was mentioned above, the predictability of the parameters of the external environment in the process of training specialists. To do this, using the chosen methodology (for example, the study of the satisfaction of the labour market with the quality of training specialists with higher education [8]), the parameters of knowledge of specialists that will be significant for employers in the foreseeable future are identified.

Secondly, it is necessary to ensure the property of controllability of the production system. For this purpose, for example, the "Quality Function Deployment" technique [11, 12,13 ] can be effective for which the results obtained at the stage of forecasting parameters of the external environment are the initial base for further application and development of design and management solutions for the management of the technological process of the university.

However, it should be realized that the educational process in the university is long (the training of a specialist lasts from 4 to 7 years) and is inert enough due to the existence of state regulation (which is expressed in the form of approval of state educational standards, state assignments, professional standards). The solution to the task of increasing the controllability of the university's production system under the indicated conditions is seen in the following. Indeed, the entire process of training specialist is inertial, but this process can be divided into several stages, each of which can be more "mobile" in terms of compliance with the requirements of the external environment. The first stage is basic (lasts from 3 to 4 years). At the basic stage, professionally significant qualities of person are formed (communication skills, dedication, responsibility, curiosity, initiative, activity, conscientiousness, etc.), personal qualities (outlook, perseverance, hard work, reliability, desire to learn, etc.). The formation of this knowledge and competencies among specialists is beyond doubt among employers and complies with state standards. As a rule, bachelors are trained for this period of time. The second stage is specialized (lasts from 2 to 3 years). This stage should be implemented directly in the interests of employers and in cooperation with them (graduating specialists "on order"). At this stage, the characteristics of specialists significant to the employer are formed, such as the availability of professional knowledge (knowledge of modern technologies, the ability to work with the tools of searching and processing information), extraordinary thinking ("fresh eyes" on the task solutions, production, innovative thinking). The duration of this stage does not go beyond the 
foreseeable forecasts of the emergence of innovations, which makes the knowledge of each output of specialists appropriate to the external environment.

In general, the implementation of the proposed approaches to the reconstruction of production systems will contribute to the formation of the properties of adaptability in higher institution, i.e. such properties that currently it has neither in terms of "predictability", nor in terms of "manageability".

\section{Conclusion}

We can distinguish three periods in the process of the historical development of the human community, three waves of civilization - pre-industrial, industrial and post-industrial society. Each of these periods is characterized by a certain level of development of productive forces, speed and volume of accumulation of new knowledge, as well as technology transfer of this knowledge to the rising generation (Table 1).

Table 1. Characteristics of the parameters of the external environment and the principles of transferring knowledge to the rising generation at various stages of social development.

\begin{tabular}{|l|l|l|l|}
\hline \multicolumn{1}{|c|}{$\begin{array}{c}\text { Stage of social } \\
\text { development }\end{array}$} & \multicolumn{1}{|c|}{$\begin{array}{c}\text { Properties of the } \\
\text { environment }\end{array}$} & \multicolumn{1}{|c|}{$\begin{array}{c}\text { Principle of } \\
\text { training }\end{array}$} & $\begin{array}{c}\text { Technology of } \\
\text { training } \\
\text { specialists in } \\
\text { educational } \\
\text { institutions }\end{array}$ \\
\hline Pre-industrial society & $\begin{array}{l}\text { Stable, predictable, lack of } \\
\text { competition }\end{array}$ & "Do the same way" & $\begin{array}{l}\text { Following the } \\
\text { traditions }\end{array}$ \\
\hline Industrial society & $\begin{array}{l}\text { Weakly variable, } \\
\text { predictable, weak } \\
\text { competition }\end{array}$ & $\begin{array}{l}\text { "Do what you are } \\
\text { told" }\end{array}$ & "Mass production" \\
\hline Post-industrial society & $\begin{array}{l}\text { Highly volatile, difficult to } \\
\text { forecast (on the verge of } \\
\text { predictions), high } \\
\text { competition }\end{array}$ & $\begin{array}{l}\text { "Think, study, } \\
\text { suggest, change, } \\
\text { change yourself" }\end{array}$ & "Serial production" \\
\hline
\end{tabular}

The problem solution of the effectiveness and viability of higher institution in the context of post-industrial transformations requires a fundamental change in approaches to the formation, organization and effective management of its production system. It requires a transition to a strategy that can be called a strategy of "cost-effective adaptation" [6]. Implementation of this strategy involves a purposeful change in the principles of building production systems in such a way that both the control object and the control system can change their parameters and structure at a rate greater than the rate of change in the parameters of the external environment.

In the conditions of post-industrial changes, continuous innovations and ever-increasing competition, the growth of environmental loads and social tension, not only the success and growth rate of both individual business systems and the economies of entire countries, but also the ability of the human community to solve the relevant tasks of their sustainable development, will depend on the ability of higher institution to change, transform continuously and actively reproduce new knowledge, its ability to pass on to their rising generation.

\section{References}

1. K. Marx, Capital, Volume III (International Publishers Co, Inc., 1967) 
2. D. Bell, The coming of post-industrial society: A venture of social forecasting (Basic Books, 2004)

3. A. Toffler, The Third Wave (AST, New York, 2010)

4. K. Schwab, The Fourth Industrial Revolution (Crown Business, London, 2017)

5. V. Mikhalchenko, Y. Rubanik, IOP Conf. Ser.: E. Env. Sci., 45, 1 (2016)

6. J. P. Womack and D.T. Jones, Lean Thinking. Banish Waste and Create Wealth in Your Corporation (Free Press, New York, 2003)

7. Z. Brzezinski, Between Two Ages. America's Role in the Technetronic Era (The Viking Press, Oslo, 1970)

8. V. Mikhalchenko, I. Seredkina, E3S Web Conf., 15, 04005 (2017)

9. Ph. Coombs, The World Crisis in Education: The View from the Eighties (Paperback, New York, 1985)

10. J. G. Wissema, Towards the Third Generation University: Managing the University in Transition (Edward Elgar, London, 2009)

11. V. Mikhalchenko, I. Seredkina, E3S Web Conf., 21, 04006 (2017)

12. L. P.Sullivan, Q. Pr., 06, 39 (1986)

13. J. L. Brossert, Quality Function Deployment (ASQ Quality Press, Milwaukee, 1990) 